\section{Commentary: That's all folks! But what should we really do to repair the aortic valve?}

\author{
Luca Weltert, MD, ${ }^{\mathrm{a}, \mathrm{b}}$ Erin Mils Iannacone, MD, ${ }^{\mathrm{c}}$ \\ Ruggero De Paulis, MD, ${ }^{\mathrm{a}, \mathrm{d}}$ and \\ Mario Gaudino, MD, MSCE, FEBCTS, FACC
}

Aortic valve repair as a therapeutic approach was first described in the $1960 \mathrm{~s}^{1}$ but never took hold as a surgical standard in the way seen with mitral valve repair. The reasons behind this are multifactorial: unsatisfactory results in early reports, the less-robust quality of aortic cusp tissue, a developing knowledge of complex aortic root anatomy, the continuous improvement of bioprosthetic tissues, and escalating endovascular technologies. Furthermore, the implantation of a prosthetic valve, whether mechanical or biological, has always been perceived as safe, durable and satisfactory, despite the well-known drawbacks to this approach. $^{2}$

On the other hand, aortic valve repair requires the honing of nuanced technical skills, a longer learning curve, and the chance of incurring failures that are particularly difficult to accept in a young patient cohort for whom valve repair is the most beneficial. Aortic valve repair has thus remained a small niche in the surgical armamentarium of a few specialized centers and surgeons dedicated to transforming a somewhat empiric approach into a codified and reproducible surgical technique. ${ }^{3}$

The article by Zhu and $\mathrm{Woo}^{4}$ provides an overview of the knowledge gained through decades of commitment to

\footnotetext{
From the ${ }^{\mathrm{a}}$ Heart Surgery Division, European Hospital, Rome, Italy; Departments of ${ }^{\mathrm{b}}$ Statistics, and ${ }^{\mathrm{d}}$ Heart Surgery, San Camillus International University for Health Sciences, Rome, Italy; and ${ }^{\mathrm{c}}$ Department of Cardiothoracic Surgery, Weill Cornell Medicine, New York, NY.

Disclosures: The authors reported no conflicts of interest.

The Journal policy requires editors and reviewers to disclose conflicts of interest and to decline handling or reviewing manuscripts for which they may have a conflict of interest. The editors and reviewers of this article have no conflicts of interest.

Received for publication Feb 2, 2021; revisions received Feb 2, 2021; accepted for publication Feb 4, 2021; available ahead of print Feb 8, 2021.

Address for reprints: Mario Gaudino, MD, MSCE, FEBCTS, FACC, Department of Cardiothoracic Surgery, Weill Cornell Medicine, 525 E 68th St, New York, NY 10065 (E-mail: mfg9004@med.cornell.edu).

JTCVS Techniques 2021;7:117-8

2666-2507

Copyright (C) 2021 The Authors. Published by Elsevier Inc. on behalf of The American Association for Thoracic Surgery. This is an open access article under the CC BY-NCND license (http://creativecommons.org/licenses/by-nc-nd/4.0/).

https://doi.org/10.1016/j.xjtc.2021.02.008
}

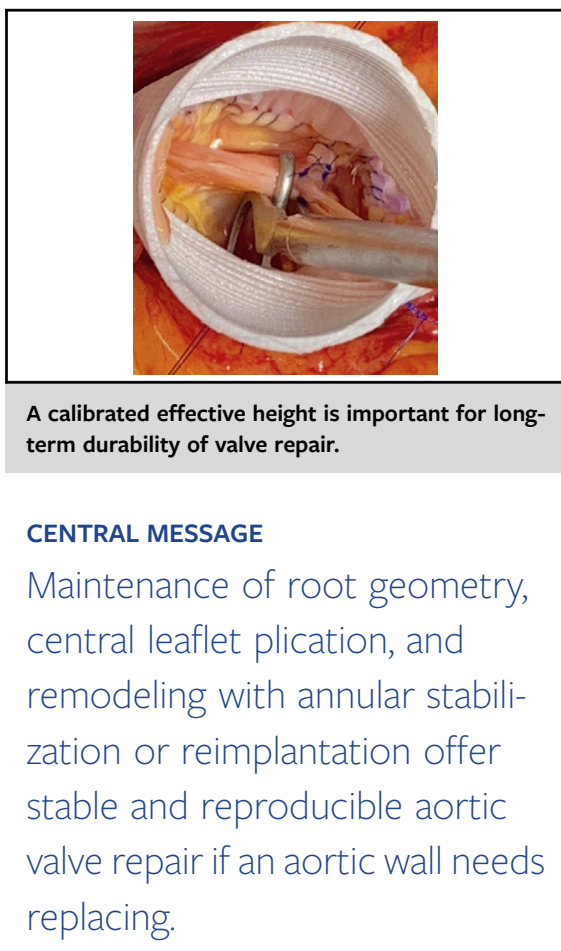

achieving reliable aortic valve repair. The authors invite us to wholly understand the advancements that support the current state of the art.

It is important to highlight the principles of valve repair strategy to which one should strongly adhere, as well as the pitfalls that should be avoided. It is clear that reestablishing or maintaining the geometry of the various components of the skeleton of the root (ie, annulus, sinotubular junction, and commissural posts) is of paramount importance before attempting any approach to the aortic leaflets. ${ }^{5}$ When working on the skeleton of the root, we have learned to be cautious of subcommissural annuloplasty because it can hamper the physiological function of the interleaflet triangles, incompletely support the annulus, and predispose to early repair failure. In addition, the natural ratio between the ST junction and the annulus must be preserved whether the root is replaced or not.

As for the approach to the aortic cusp, commissuroplasty is not preferred because it is performed in the area of greatest stress for the aortic leaflets. Lateral plication of the leaflet can lead to challenges in maintaining symmetry of the cusp and in ensuring an adequate final coaptation. ${ }^{6}$ Conversely, central plication has proven to be a reliable and reproducible technique, especially in cases of a tricuspid valve where the other portions of the free margin are thinner and more fragile. ${ }^{7}$ 
Finally, analysis of the results from the most experienced centers indicates that extensive use of pericardium leads to poor outcomes. ${ }^{8}$ In valves where tissue is lacking, the wellknown saying less is more, appears appropriate. It is reliably better to isolate the use of pericardial patches to the belly of the leaflet rather than extending their use to the commissures.

There are few tenets to aortic valve repair, but those few are well accepted and reliable. These include maintenance of aortic root geometry and the use of central leaflet plication for prolapsing leaflets. If an aortic wall needs to be replaced, remodeling with annular stabilization ${ }^{9}$ and reimplantation ${ }^{5}$ offer 2 options to properly restore the skeleton of the root.

The time has come to disseminate these procedures by establishing systematic techniques and a standardized approach. Profound knowledge of the anatomy and new, repair-oriented classifications will encourage a more precise evaluation of both the dysfunctional and the repaired valve in different anatomical conditions. Finally, the ability to offer successful and durable aortic valve repair will promote earlier surgical referrals with direct advantages in terms of cardiac morbidity and quality of life.

\section{References}

1. Bailey CP, Brest AN, Donstas N, Uricchio JF. Successful repair of aortic insufficiency due to valvular fenestration. Circulation. 1959;20:587-9.

2. Goldstone AB, Chiu P, Baiocchi M, Lingala B, Patrick WL, Fischbein MP, et al. Mechanical or biologic prostheses for aortic valve and mitral-valve replacement. $N$ Engl J Med. 2017:377:1847-57.

3. Malas T, Saczkowski R, Sohmer B, Ruel M, Mesana T, de kerchove L, et al. Is aortic valve repair reproducible? Analysis of the learning curve for aortic valve repair. Can J Cardiol. 2015;31:1497. e15-22.

4. Zhu Y, Woo YJ. Cusp repair techniques in bicuspid and tricuspid aortic valves. $J$ Thorac Cardiovasc Surg Tech. 2021;7:109-16.

5. David TE. Aortic valve sparing in different aortic valve and aortic root conditions. J Am Coll Cardiol. 2016;68:654-64.

6. Mangini A, Contino M, Romagnoni C, Lemma M, Gelpi G, Vanelli P, et al. Aortic valve repair: a ten-year single-centre experience. Interact Cardiovasc Thorac Surg. 2014;19:28-35.

7. Settepani F, Cappai A, Raffa GM, Basciu A, Barbone A, Berwick D, et al. Cusp repair during aortic valve-sparing operation: technical aspects and impact on results. J Cardiovasc Med. 2015;16:310-7.

8. Karliova I, Schneider U, Ehrlich T, Schäfers HJ. Results of pericardial patches in tricuspid and bicuspid aortic cusp repair. Ann Thorac Surg. 2020;109:728-35.

9. Lansac E, Di Centa I, Sleilaty G, Lejeune S, Khelil N, Berrebi A, et al. Long-term results of external aortic ring annuloplasty for aortic valve repair. Eur J Cardiothorac Surg. 2016;50:350-60. 